\title{
SASKATCHEWAN BIRD BANDERS: HARRY L. FELT OF FINDLATER, BANDER $007^{*}$
}

\begin{abstract}
C. STUART HOUSTON, 863 University Drive, Saskatoon, Saskatchewan. S7N OJ8
\end{abstract}

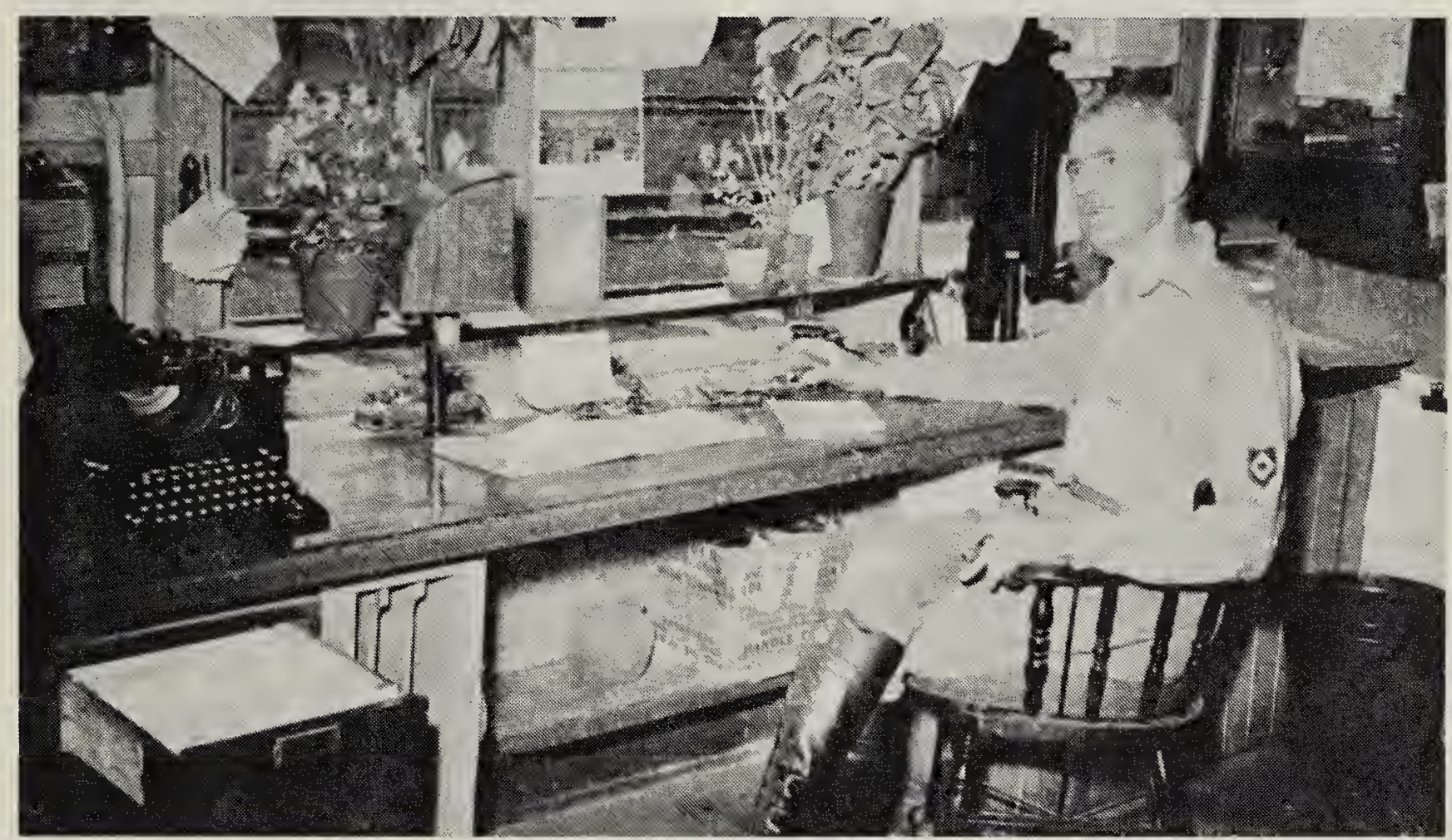

Hamy L. Felt, Findater, late 1930s.

Harry Lee Felt was born 3 March 1882 to Alonzo Sydney Felt and Mary Louise Felt, née Whittier, at Portland, lowa, a village laid out on the old Felt farm near Mason City. Harry was the youngest of nine children of parents from New York, who pioneered in lowa in the 1850s and were married at Osage, lowa, in 1857. His father died when he was only 10 . His mother moved to Mason City where Harry received his education, worked as a messenger for the Western Union Telegraph Company, learned telegraphy, and entered the employ of the Chicago and Northwestern railroad. $\mathrm{He}$ was lowa's top long-distance bicycle racer. On New Year's Day, 1903, he married Grace M. Smith.

In 1910, while returning from a hunting trip to the Canadian Rockies, he was attracted by the upland game hunting possibilities on the prairies. "Answering the call of the wild" as the Nashua Reporter stated, he took relieving jobs at Saskatoon, Disley, Condie and Prince Albert before settling down as the CNR agent at Findlater, Saskatchewan.

\section{Bird Banding}

In 1922, Harry Felt was the second Saskatchewan resident to obtain a bird

- Number 17 in a series of biographies of Saskatchewan bird banders. 


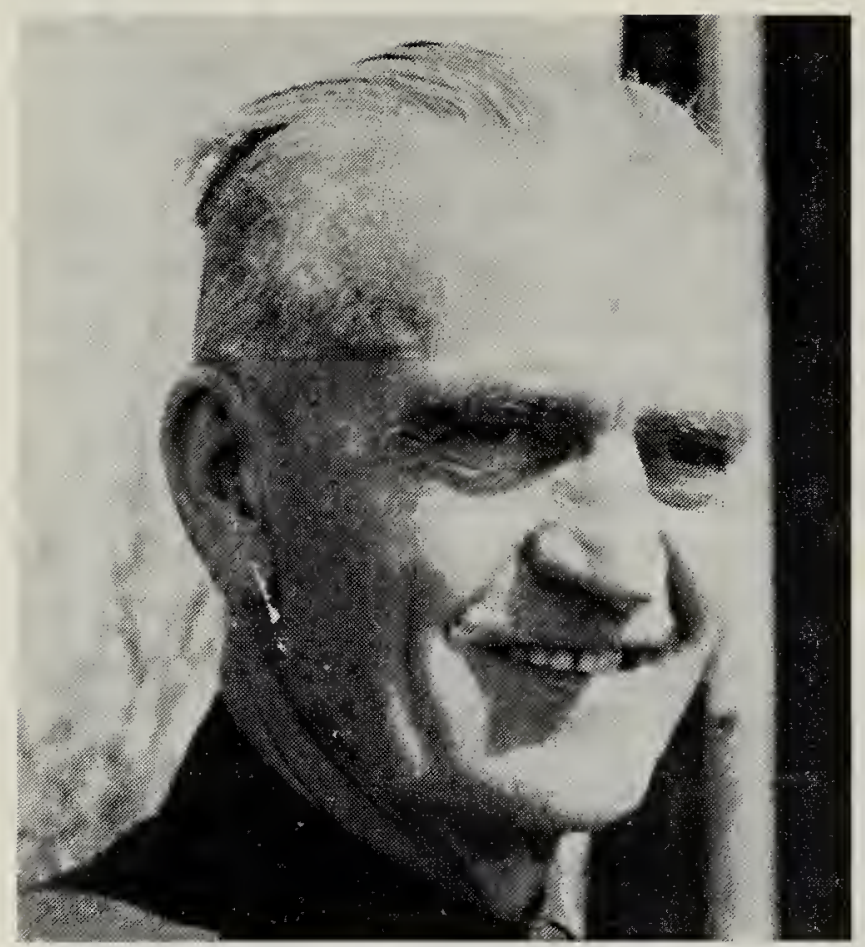

Hamy L. Felt, Findater.

banding permit, one year following Fred Bradshaw, the Game Commissioner in Regina Later, when numbers were given each permittee in North America, Bradshaw was assigned number 002 and Felt 007.

The computer printout that lists a single Gadwall or "gray duck" banded by Felt in 1920 is presumed to be in error. In 1922, he banded 3 hawks, 18 Mallards, 2 Wigeon, 2 Greenwinged and 3 Blue-winged Teal, 2 Shovelers and 2 Pintails. Pintail 202404, banded at Findlater on 9 July 1922, was killed near Camp Crook, South Dakota on 4 November 1922. Another "gray duck," 202420, was shot at Bayou Cocadie, three miles north of Catau, Louisiana. One of the three nestling hawks, 202406, banded 4 August 1922, probably a Swainson's Hawk, but entered in the computer as "Goshawk", was shot at Bostwick, Nebraska, on 26 April 1926.

Felt became more active in 1925 , banding 1 "hell-diver" (Horned Grebe?), 3 Mallards, 10 Blue-winged Teal, 4 each of Northern Shoveler and Gadwall, 14 Redheads, 4 Lesser Scaup, 4 Cliff Swallows and 2 Eastern Kingbirds that year.

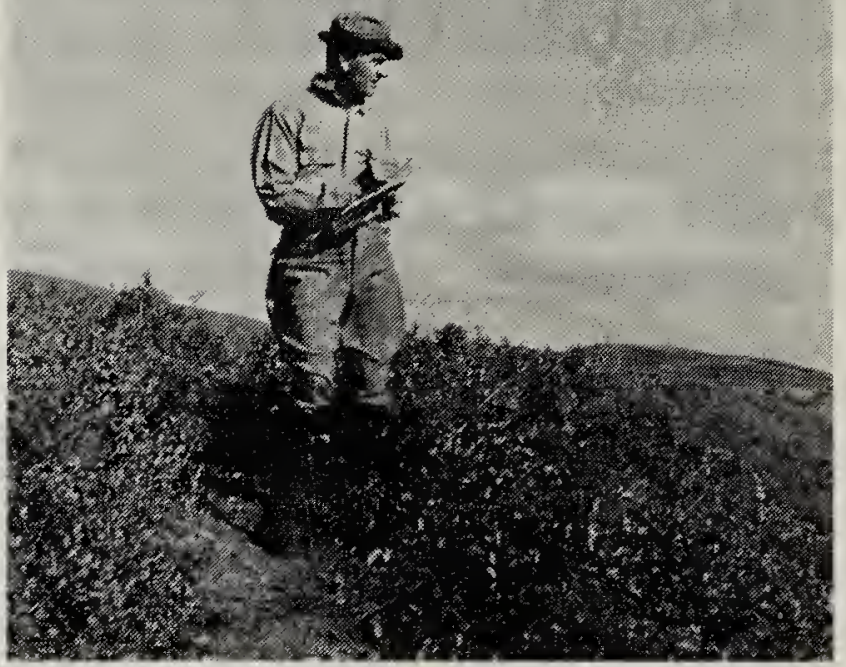

Harry L. Felt, Findater.

A record card was filled out for each bird and mailed to the banding office, but 1925 was the only year that Felt kept a typewritten copy of species and dates for his own records. Bands were not always used in chronologic order. The cards were filled out in pencil, whereas they were supposed to be written in ink. There were no guides to help banders identify immature ducks and there were resultant discrepancies between the species as identified by Felt and as reported when shot by the hunter. Felt explained in a letter of 11 December 1925 to the banding office: "Most of these cards were made up by my assistant, being dictated by myself at the time of actual banding. It is a possibility a number may have been given in error, as a good many birds were banded at dusk, evening being the only time that I could get away to do the work."

There were four recoveries that fall. A "Redhead", 321689, was shot four miles east of Lumsden, Saskatchewan, on 28 September; a "Redhead", 321693, reported by the hunter as a "bluebill", was shot at Lake Park, Minnesota, on 25 October; another Redhead, 321686, reported as a teal, was 
shot near Frazee, Minnesota, on 10 November; and a "Redhead", 321658, reported as a Lesser Scaup, was shot at the Netherlands Gun Club, Lake Cataouche, Louisiana, on 28 November.

The Felt permit 007 file is incomplete but records that he banded one Gadwall and one Shoveler in 1928. An interesting letter concerns a "Sharp-shinned Hawk" banded by someone else for him, near Findlater on 4 August 1930. This hawk was "caught" on 17 December 1932 by a 17-year-old boy, Daly Hodges, and an 18-year-old boy, J.B. Cotham, at Savoy, Texas. They kept the hawk in a cage and wrote asking what they should do with it.

He banded at least one Red-tailed Hawk on 4 August 1931. A Ferruginous Hawk, 321882, was banded by him but the date of banding was lost. This hawk was shot by Alex Laing of Bethune, Saskatchewan, on 3 Fobruary 1934, an interesting winter record for this species.

\section{Hunting and Guiding}

Happily situated between Buffalo Pound Lake and Last Mountain Lake, Harry Felt enjoyed hunting and fishing. His American friends made Findlater their stopping place to hunt the lakes crowded with ducks and stubble fields populated with Sharp-tailed Grouse. Soon he was earning extra money by guiding sportsmen, who included the well-known outdoor writer Grantland Rice; Ray Holland, editor of Field and Stream, and W.B. Mershon, author of Recollections of my Fifty Years Hunting and Fishing. Jimmy Robinson, author and hunting columnist in Minneapolis, wrote that, "Perhaps the best known of all duck obsenvers is Harry L. Felt of Findlater, Sask."

A special siding was constructed at
Findlater for a private railway car when the Prince of Wales visited, and the siding was used in subsequent years by American millionaires who brought their own private railway car, complete with a refrigeration unit, which parked on this siding. The CNR made a special power and water installation to accommodate them. Mrs. Felt had their residence filled with hunters as well, and hosted at least 250 American hunters over the years.

Harry Felt was famous for breeding Chesapeake retrievers and owned a prize English setter. Six of the millionaires buitt a hunting lodge on Buffalo Pound Lake in 1920 and used it until 1944 when the last of the six died. Felt was not only the guide for these hunters, but cared for the lodge in the off-season and latterly took full charge of the operation.

\section{Crow and Magpie Campaign}

When Felt arrived at Findlater, there were few crows and no magpies. After the crow population increased greatly in the 1920 s, Felt found that $85 \%$ of duck nests were being destroyed by crows.' In 1930, feeling that ducks could not withstand drought and crows combined, he began a one-man campaign against crows. Using a mounted Great Horned Owl on a tripod and a 20-gauge shotgun, he shot several thousand crows over the years. Beginning in 1932, he bought a silver cup as prize for the most crows destroyed by children of a single rural school. He paid one cent per crow egg and half a cent per magpie egg, spending about $\$ 700$ over ten years for the campaign amongst 14 neighboring rural schools.

In 1938, for example, Gladstone and Edwards schools amassed the most points, led by Lloyd Gemmell of Edwards school, who pocketed the princely sum of ten dollars. That year children destroyed 6383 crow and 337 
magpie eggs, and shot 1428 crows and 129 magpies. In 1940, the cup went to Goldridge school, south of Dilke. In eight years the children destroyed 30,000 crow and magpie eggs and Felt claimed that by concentrating this campaign in a local area, that only $5 \%$ of local duck eggs were lost to crows. In 1934 and 1935, studies by E.R. Kalmbach found that at least $31 \%$ of duck nests at Waterhen Lake near Kinistino were destroyed by crows. ${ }^{2}$

In 1934, 121/2 years after Gray Partridge reached Saskatchewan from their introduction in Alberta, Ray Holland challenged Felt's statement that he could put up 50 coveys of Hungarian Partridge in one day; Felt countered by showing Holland 95 coveys within an area of 25 square miles. Felt attributed this high density to the success of his crow campaign.

Following Felt's example, the Saskatchewan Fish and Game League (now the Wildife Federation) initiated a province-wide crow campaign amongst school children. This was ill-advised and pressure by the Saskatchewan Natural History Society in the 1950 s helped its demise. While strict control of predators in a specific area is today under research study by both the Canadian Wildife Service and the biologists at the Northem Prairie Wildlife Research Center, Jamestown, North Dakota, scatter-gun province- wide approaches tend to kill fewer than the annual crop of predators and thus are ineffective, while teaching school children to shoot rather than conserve.

Harry Felt was a Voluntary Game Guardian and a charter member of the Fish and Game League. As one of the first kee-men for Ducks Unlimited, he guided Tom Main in his area and appeared in a Ducks Unlimited promotional movie, "The Prairie Duck Factory", and a Trans-Canada Airlines movie, "Duck Shooting in Western Canada". His other outdoor activities clearly provided more satisfaction than did his early experience in banding birds.

Upon retirement in 1946, the Felts returned to Mrs. Felt's home town of Nashua, lowa. Here Harry Felt died on 3 February 1959, after a lengthy illness.

\section{Acknowledgements}

I wish to thank Hary Felt's daughter, Mrs. Dorothy S. Palmer of Topaz, Califomia, for loan of her father's precious scrapbook and mementos. I leamed her address from her childhood friend, Mrs. Mary Carment of Prince Albert, whose phone number in tum was given me by Isobel Waters of Findlater.

1. FELT, H.L. 1945. Jim Crow, the killer. Game Trails in Canada, pp. 10-11.

2. KALMBACH, E.R. 1937. Crowwaterfowl relationships, based on preliminary studies on Canadian breeding grounds. United States Dept. of Agriculture Circular 433. Washington. $35 \mathrm{pp}$.

On the 26 December 1989 Christmas Bird Count at Pine Prairie, Lousiana, observers estimated 53,000,000 Redwinged Blackbirds, 20,000,000 starlings, 5,000,000 cowbirds and 3,000,000 Common Grackles. American Birds 44:843. 